\title{
The Artist in/and Me Crónica
}

\section{Susana Chávez-Silverman, Pomona College}

Heatwave $4^{\text {th }}$ of July, 2011

Claramonte, Califas

For Juan Muñoz Torregrosa, in memoriam

Today's the fourth of july Another june has gone by

And when they light up our town I just think

What a waste of gunpowder and sky

I'm certain that I am alone

In harbouring thoughts of our home

It's one of my faults that I can't quell my past ...

' 4 th of July,' Aimee Mann [http://www.youtube.com/watch?v=3S7HAvibdvc]

Un long ago and faraway enero en los early '70s - decade que abriría en una España tenebrosa, mysterious y franquista y cerraría a plena Movida (pero esa es otra ...) - mi hermana Sarita met this oke named Vicente Muñoz Torregrosa. Ella le había visto, on the other side of the street, en Madrith. She went into a papelería, where we used to buy the little square-printed paper, hilos para bordar, that sort of thing. El la siguió. Mi hermana tenía sólo 14 años, pero era, let's say, bahtante well-developed for her age, habiendo emposhado busto, and gotten her rule, etc at a super-young age, maybe even when she was 9 or 10 . No me acuerdo bien. Pero way before me, en todo caso.

Anygüey, la cosa es que in a matter of a few months, Sarita se enamoró de este Vicente oke. No me acuerdo exactamente cómo comenzó, pero I got involved with his younger brother, Juan. Vicente era dark and smoldering; he oozed danger, y tenía cierto aire 
mesiánico. Juan era espigado, lánguido. Long long legs and a small butt, long waist y pelo lacio, fino, tirando a wispy, light brown. Tenía una cara larga, nariz larga y elegante, slightly down-turned dark eyes y sobre todo, una mirada entre melancólica y sardónica. Sad and knowing a la vez. Tenía 18 años, y yo 15. Vince was 21.

Vicente hizo la corte a mi hermana. Oh yeah. Hablaban de política (he was AWOL del ejército franquista, I remember), de arte, she would tell me at night, breathlessly. Tenía que hacer sneaking out para reunirse con él, OB-vio. Creo recordar que Vicente was in some kind of trouble (hiding from Franco's draft? La familia? O quizás some of both ... no sé) y que poco después de despojarla de su virginidad, he disappeared. Puf! Right out of Madrid. Esto lo recuerdo porque Sarita dreamed of him a couple of months later, en la primavera, when we were on a family vacation con los Golden, en Andalucía. Sarita soñó con Vicente en Cádiz, and then we saw him again, en la calle, en Sevilla. Can you believe that? Acompañado de una hippie dippie, wistful, slightly lela Canadian girl, una tal Rose Brown. Slightly older than us, creo. Pero esa es otra.

Con Juan, en esos winter Madrid months, I used to love to study his mournful, contained Spanish profile. Tenía una boca hermosa, me acuerdo. We went to Buster Keaton movies, con mi hermana y con Vicente. Juan me hablaba de cosas que yo no conocía, pero I should have. I should have, more than he. I was the American girl, pero era él, un adolescente madrileño en la España de Franco, quien me llevaba de la mano (me in my stupid, awkward camel hair Corte Inglés abrigo que me parecía tan sophisticated, tan elegante) a la Biblioteca Washington Irving, para sacar libros de los poetas norteamericanos e ingleses que él adoraba: Ted Hughes, Sylvia Plath, John Berryman, Robert Lowell. Pero sobre todo Thom Gunn.

Thom Gunn was a revelation: dark, peligroso, erudito, yearning, muscular, erotic.

Juan Muñoz Torregrosa lit the fire of poetry in me. Poetry en inglés, in $m y$ language, on wintry afternoons in his country, en la Biblioteca Washington Irving de Madrid. Or walking walking walking. O, más tarde, en un colchón on the floor of a dim, slightly cutre ático que supongo (ahora) pretendía hacer de bohemian artist's studio.

Oh, ese colchón. Las manos de Juan. Sus corduroy pants. Their zipper. Por algo (no creo en las concidencias: this is a well-known fact) I must've been having flashbacks, 
these past few months, estas extrañas imágenes que me remitían a Juan. But I didn’t know why. Hasta ahora.

Anygüey, it was cold that winter, gris y despiadado, and I was scared, apprehension winning out against el enticing feel de su hard-on under my tentative, curious hand, straining against el velvety, narrow-wale fawn-colored corduroy bell bottoms as we lay en ese colchón, his fine beigey hair falling past his cheekbones, falling into my face mientras nos besábamos y tocábamos, his sexy jutting hipbones angled into me, rubbing against each other frenetically, semi-desnudos, hambrientos y melancólicos in that icy room.

Yo tenía 15 años, no birth control, y había tricornio-wearing, rifle-toting Guardia Civil all over the show, practically en cada esquina, te lo juro. Esos tiempos eran eróticos pero forbidding. And I was not as bold as my sister, not by half.

Supongo que cuando Vince flew the coop, y se fue de Madrid, Juan and I faded out of each other's lives too. Yo retuve de él un único regalo: The New Poetry, una antología with Jackson Pollock's aptly-titled 'Convergence' en la portada y la contratapa, Juan Muñoz Torregrosa's name written inside, y sus apuntes and laborious, correct, idiomatic translations into Spanish of difficult words and phrases al margen.

Subí a checar, ahorita mismo, si todavía tenía este libro, upstairs, en mis estantes. And there it was. Just as I remembered it, when he gave it to me hace tantos y tantos años, en España. In another Spain. Es un libro pequeño, deceptively small considering its lifechanging contents: 'The Separation,' de Thom Gunn, que haría jumpstart mi obsesión con 'The Turn of the Screw.' And Gunn's 'The Feel of Hands.' Esos poemas articulaban del amor y del sexo lo que yo no podía, entonces. Nor he either, exactly, quizás. Gunn said it to us, spoke for us. Both of these poems Juan marked for me, para que yo los leyera particularmente.

Si hubiese tenido que decir, adivinar, proyectar hacia el futuro, I would've said Juan Muñoz Torregrosa would be a writer. A poet. Tenía el look, mos def: huraño-expansive, sad-eyed teenage flaneur. And the obsessive, devotional passion for las palabras. Pero he became an artist. ¿Que cómo lo sé? Ah, the miracles of CaraBobo, el Internido. A mi hermana, hace pocos días le dio por hacer sleuthing on Vicente, just like that. 
Bueno, not quite 'just like that.' Dijo que mi reconnection con Howard, todo nuestro remembering - all my memory-work, como quien dice, en estos últimos 3 años-mi reigniting con mi Montenegro, la hizo pensar en Vince. Lo encontró: he's some kind of New Age-y healer, o gurú, o shamán. Something like that. ¿Te imaginas? En las afueras de Madrid. En Majadahonda. Samarpan, he goes by. Hasta tiene su propio CaraBobo page y todo. Muy 'her,' digo, muy mi hermana, if I do say so. Kind of eerily perfect, en realidad.

Con un poquito más de sleuthing, a instancias mías, she discovered that Juan became an internationally-renowned escultor, pintor y spoken word artist. Hasta hangueaba con los likes of John Malkovich and John Berger: 2 saints of my devotion, if there ever were ones.

Se casó con una artista española que conoció en sus 20s en Londres, where he'd moved to, para escapar esa ominosa sombra franquista, as soon as he could. Only a few years, actually just a couple of years, after I'd known him.

Tuvo exposiciones all over Spain, England, hasta los EE.UU. Hay websites y blogs y BoobTube videos all over the show. Hasta está en Wikipedia. All that, pero I said 'tuvo,' past tense, porque he's dead. Eso es lo más fuerte. Lo insoportable, really. Can you believe this? Nos da por rastrearlo, a Sarita y a mí, y descubrimos que he's gone. He died suddenly, of a massive aneurisma, en Ibiza, a los 48 años. Ten years ago.

La viuda, Cristina Iglesias (herself a well-known artista), ha hecho moving on, como quien dice, y ahora es la dizque compañera sentimental de un Mexican-born, zilliontrillion-multimillonario algo abueleril: un vato relacionado con el Museo Reina Sofía, creo. Or the Prado. Maybe both. And also, agarrate, while we're at it, también tiene algo que ver con los VIPS restaurants, TGI Viernes and a bunch of other places. Te lo juro.

Anygüey, all the rest of it, the fame part, Juan's strangely alive, slightly smaller than lifesize esculturas figurativas, stitching and challenging the edges entre lo público y lo privado, pieces lit up by that loquacious, playful yet also cerebral and uncompromising Gemini-energy? Pues esa es otra historia. 